\title{
BASINDO
}

Jurnal Kajian Bahasa, Sastra Indonesia, dan Pembelajarannya

Vol 1 No 1 - April 2017 (72-86)

\section{PEMBELAJARAN GAYA BAHASA (BASA RINENGGA) PADA SISWA KELAS VIII}

\author{
Lusi Ari Agustin \\ E-mail: agustinariisul@gmail.com \\ Anang Santoso \\ Universitas Negeri Malang, Jalan Semarang 5 Malang
}

\begin{abstract}
ABSTRAK: Tujuan penelitian adalah (1) mendeskripsikan perencanaan pembelajaran basa rinengga terkait komponen RPP, (2) mendeskripsikan interaksi siswa dan guru yang terdiri atas kegiatan: awal, inti, dan penutup, (3) mendeskripsikan penilaian sikap, keterampilan, dan pengetahuan. Penelitian ini termasuk penelitian kualitatif dengan pendekatan wacana kelas. Hasil penelitian adalah (1) RPP dirancang sesuai komponen (2) pelaksanaan kegiatan awal meliputi apersepsi, presensi, dan motivasi; kegiatan inti mencakup pendekatan saintifik; kegiatan penutup berupa refleksi, (3) penilaian sikap, berupa observasi; penilaian keterampilanberupa unjuk kerja; dan penilaian pengetahuanberupa ulangan harian dan tanya jawab.
\end{abstract}

Kata kunci: pembelajaran, basa rinengga, perencanaan, pelaksanaan, dan penilaian

\begin{abstract}
The purpose of this research is (1) describe the learning plan related components RPP rinengga language, (2) describe the interaction of students and teachers, it consists of: initial, core and cover, (3) describes the assessment is the attitude, skills and knowledge. This study included a qualitative research approach classroom discourse. The results of the study are (1) RPP is designed according to component (2) implementation of initial activities include apersepsi, presence, and motivation; core activities include scientific approach; cover activities such as reflection, (3), the assessment, in the form of observation; skills assessment in the form of their performance; and assessment of knowledge in the form of daily tests and debriefing.
\end{abstract}

Keywords: learning, rinengga language, planning, implementation, and evaluation

Pembelajaran bahasa Jawa penting bagi siswa sebagai sarana pembentukan budi pekerti dan sopan santun serta mengangkat kembali nilai-nilai kearifan lokal bangsa.Pembelajaran bahasa Jawa merupakan muatan lokal yang sudah dipelajari mulai dari jenjang sekolah dasar hingga sekolah menengah atas, bahkan dalam 
kehidupan sehari-hari sudah menggunakan bahasa Jawa sebagai bahasa daerah, utamanya di Jawa Timur.

Fakta saat ini banyak anak-anak di Indonesia dengan latar belakang orang Jawa yang menggunakan bahasa Indonesia sebagai bahasa sehari-hari mereka. Fenomena ini dikarenakan keadaan pendidikan saat ini yang menekankan anak-anak usia dini menggunakan bahasa asing daripada bahasa Jawa. Padahal dalam bahasa daerah terkandung pendidikan budi pekerti yang luhur yang dapat dicontoh. Akibatnya sedikit demi sedikit identitas bahasa daerah ini mengalami kemerosotan dari segi penggunanya.

Dalam kedudukannya sebagai bahasa daerah, bahasa Jawa memiliki beberapa fungsi. Adapun fungsi bahasa Jawa menurut Sabdawara (2001:127-128) antara lain: (1) bahasa Jawa adalah bahasa budaya disamping berfungsi komunikatif juga berperan sebagai sarana perwujudan sikap budaya yang sarat dengan nilai-nilai luhur, (2) sopan santun berbahasa Jawa berarti mengetahui akan batas-batas sopan santun, mengetahui cara menggunakan adat yang baik dan mempunyai rasa tanggung jawab untuk perbaikan hidup bersama, (3) agar mencapai kesopanan yang dapat menjadi hiasan diri pribadi seseorang, maka syarat yang harus dipenuhi adalah sebagai berikut: pandai menenggangkan perasaan orang lain di dalam pergaulan, pandai menghormati kawan atau lawan, dan pandai menjaga tutur kata, tidak kasar dan tidak menyakiti hati orang lain.

Pada pembelajaran bahasa Jawa ditemukan beberapa kendala, antara lain kurangnya literatur dan rendahnya pemahaman siswa mengenai istilah bahasa Jawa. Hal ini menjadi penyebab tidak lancarnya komunikasi ketika pembelajaran. Fakta tersebut sebagai akibat rendahnya minat belajar siswa terhadap mata pelajaran bahasa Jawa. Berdasarkan hal tersebut dilakukan penelitian terhadap perencanaan, pelaksanaan, dan penilaian pembelajaran bahasa rinengga.

Tujuan penelitian ini adalah (1) untuk mendeskripsikan mengenai perencanaan pembelajaran basa rinengga yang terkait dengan komponen RPP, (2) untuk mendeskripsikan interaksi siswa dan guru dalam kegiatan belajar mengajar yang terdiri atas kegiatan awal, kegiatan inti, dan kegiatan penutup, (3) untuk 
mendeskripsikan penilaian pembelajaran basa rinengga yaitu penilaian sikap, penilaian keterampilan, dan penilaian pengetahuan.

\section{METODE}

Penelitian ini termasuk penelitian kualitatif dengan pendekatan wacana kelas.Penelitian ini dilaksanakan di SMP Negeri 2 Malang yakni di kelas VIII SMP. Data pada penelitian ini berupa (a) paparan perencanaan pembelajaran bersumber dari RPP guru bahasa Jawa, (b) paparan pelaksanaan pembelajaran bersumber dari interaksi belajar mengajar, dan (c) paparan evaluasi pembelajaran bersumber dari dokumen hasil penilaian serta proses pembelajaran dalam kelas. Sumber data pada penelitian ini diperoleh dari catatan hasil observasi, hasil wawancara, dan dokumentasi.Teknik pengumpulan data (1) peneliti melihat pedoman telaah rencana pelaksanaan pembelajaran, (2) peneliti menerapkan instrumen pada data, (3) peneliti masuk ke dalam kelas meneliti dan merekam kegiatan belajar mengajar, (4) peneliti mencatat konteks pemakaian tuturan guru, (5) peneliti mengamati dan mencatat aktivitas siswa, (6) peneliti melaksanakan wawancara mengenai data yang belum dipahami, (7) peneliti mencatat hasil wawancara, (8) peneliti mengamati proses penilaian dan hasil pembelajaran.Uji keabsahan data pada penelitian ini berupa perpanjangan pengamatan terhadap data yang sudah terkumpul.Pada penelitian ini, pengecekan keabsahan data dilakukan dengan cara, (1) uji pakar, dan (2) teman sejawat.

\section{HASIL DAN PEMBAHASAN}

\section{Perencanaan Pembelajaran Gaya Bahasa (Basa Rinengga)}

RPP merupakan panduan bagi guru dalam proses pembelajaran, guna mengembangkan kompetensi dasar. Komponen penyusunan RPP disesuaikan dengan kurikulum yang berlaku saaat ini, yakni Kurikulum 2013. Komponen tersebut mencakup (1) identitas RPP, (2) kompetensi inti, (3) kompetensi dasar dan indikator pencapaian kompetensi, (4) tujuan pembelajaran, (5) materi pembelajaran, (6) pendekatan, metode, dan model pembelajaran, (7) media/alat, bahan dan sumber belajar, (7) langkah-langkah pembelajaran, (8) penilaian.

\section{Menyusun Identitas RPP}


Penyusunan identitas RPP disesuaikan dengan jenjang pendidikan, kurikulum yang berlaku, dan silabus pembelajaran. Identitas RPP bukan hanya sebagai pelengkap. RPP mempermudah pendidik dalam membagi materi yang akan diajarkan, kapan pelaksanaan pembelajaran, berapa lama waktu yang dibutuhkan selama pembelajaran, dan di kelas apa pembelajaran akan dilaksanakan. Pendapat tersebut sudah sesuai dengan penulisan identitas RPP rancangan guru meliputi satuan pendidikan yakni SMP Negeri 2 Malang, identitas berupa mata pelajaran yaitu bahasa Jawa, identitas berupa kelas VIII semester I, materi pokok berupa basa rinengga, tema mengenai kebudayaan, dan alokasi waktu yakni 2 pertemuan (4x40 menit).

Pada kegiatan pembelajaran tema kebudayaan sudah diterapkan dengan tayangan kethoprak. Alokasi waktu yang tertulis pada RPP guru untuk kompetensi menulis hanya dilaksanakan untuk satu pertemuan atau 2 jam pelajaran. Pada keterampilan menulis merupakan keterampilan yang membutuhkan tingkat berpikir tinggi, maka alokasi waktu yang dirancang oleh guru sebaiknya dapat membantu siswa untuk mencapai kompetensi tersebut.

\section{Merumuskan Indikator Pembelajaran}

Indikator pencapaian kompetensi yang disusun oleh guru antara lain (1) mengidentifikasi berbagai jenis ragam bahasa dalam teks, (2) mengidentifikasi berbagai jenis gaya berbahasa, (3) menganalisis struktur teks yang memuat ragam bahasa dan gaya bahasa, (4) menjelaskan makna paribasan yang terdapat dalam teks, (5) membuat kalimat menggunakan gaya bahasa (basa rinengga), (6) membuat paragraf menggunakan kalimat yang memuat paribasan, (7) membaca teks yang memuat paribasan. Penentuan indikator disesuaikan dengan KI dan KD, alokasi waktu, silabus serta kondisi siswa. Berdasarkan hasil analisis, indikator yang disusun oleh guru merupakan penjabaran dari Kompetensi Dasar (KD). Poerwanti dan Amri (2013:151) bahwa indikator pencapaian kompetensi adalah perilaku yang menunjukkan ketercapaian KD tertentu yang menjadi acuan penilaian pembelajaran.

\section{Merumuskan Tujuan Pembelajaran}

Tujuan pembelajaran menggambarkan proses dan hasil belajar yang dicapai oleh peserta didik sesuai dengan kompetensi dasar yang telah di tetapkan. Tujuan pembelajaran didapatkan dari penjabaran indikator. Adapun tujuan pembelajaran 
yang dirumuskan oleh guru antara lain (1) peserta didik dapat mengidentifikasi kalimat dengan menggunakan gaya bahasa rinengga, (2) peserta didik dapat mengapresiasikan gaya bahasa rinengga dalam kehidupan sehari-hari, (3) peserta didik dapat mengidentifikasi berbagai jenis ragam bahasa dalam teks, (4) peserta didik dapat mengidentifikasi berbagai jenis gaya berbahasa, (5) peserta didik dapat menganalisis struktur teks yang memuat ragam dan gaya berbahasa, (6) peserta didik dapat menjelaskan makna paribasan, (7) peserta didik bisa membuat kalimat menggunakan gaya berbahasa, (8) peserta didik bisa membuat paragraf menggunakan kalimat yang memuat paribasan.

\section{Menentukan Materi Pembelajaran}

Perencanaan materi pembelajaran gaya bahasa (basa rinengga) yang dirancang oleh guru bersama Tim MGMP kota Malang mengenai bahasa Jawa di SMP Negeri 2 Malang disesuaikan dengan rumusan indikator pencapaian kompetensi. Penyusunan materi secara sistematis dimulai dari (1) materi fakta berupa definisi basa rinengga, jenis-jenis dan contoh basa rinengga, serta ciri-ciri basa rinengga, (2) materi konsep berupa teknik membuat paragraf, dan teknik membaca, (3) materi prinsip berupa paribasan (peribahasa dalam bahasa Jawa), (4) prosedur berupa penggunaan basa rinengga dalam kehidupan sehari-hari. Pada Kurikulum 2013 keempat jenis materi pembelajaran ini harus termuat dalam pembelajaran.

Pemilihan materi disesuaikan dengan kondisi dan tingkat kemampuan peserta didik. Materi pembelajaran yang tercantum dalam RPP terdiri atas materi fakta, materi konsep, materi prinsip serta prosedur. Hal ini sesuai dengan pendapat Poerwanti dan Amri (2013:151) menyatakan bahwa materi pembelajaran memuat fakta, konsep, prinsip dan prosedur yang relevan dan ditulis dalam bentuk butir-butir sesuai dengan rumusan indikator pencapaian kompetensi.

\section{Menentukan Metode Pembelajaran}

Metode pembelajaran dirancang guna mewujudkan suasana belajar yang menyenangkan sehingga kompetensi ataupun indikator yang telah di tetapkan dapat dicapai oleh peserta didik. Metode pembelajaran yang digunakan dalam pembelajaran gaya bahasa (basa rinengga) ini adalah (1) tanya jawab, (2) diskusi, dan (3) inkuiri dengan pendekatan saintifik. Pemilihan metode pembelajaran pada RPP guru sudah 
mencakup seluruh langkah-langkah pembelajaran, metode inkuiri dan discovery learning belum efektif penerapannya. Berdasarkan temuan yang terdapat dalam RPP, pendekatan saintifik dalam pelaksanaannya pada kegiatan inti hanya terlihat beberapa komponen yang muncul dari keseluruhan komponen.

\section{Menentukan Media serta Sumber Belajar}

Sumber belajar dapat membantu siswa dalam belajar dengan baik, selain itu sumber belajar tidak harus berupa buku-buku. Sumber belajar dan media pembelajaran perlu ditentukan dalam perencanaan pembelajaran, dengan tujuan dapat mendukung lancarnya kegiatan pembelajaran. Sumber belajar yang terdapat di dalam RPP ialah (1) majalah jayabaya, (2) buku paket bahasa Jawa, (3) pepak bahasa Jawa. Berdasarkan hasil temuan, guru belum menggunakan majalah jayabaya melainkan menggunakan tiga buku penunjang yakni buku paket bahasa Jawa dan LKS bahasa Jawa. Sumber belajar berupa buku paket bahasa Jawa di dapatkan dari Kementrian Pendidikan dan Kebudayaan. Sumber belajar yang digunakan kurang variatif. Pemilihan sumber belajar bisa juga dengan melihat hal-hal yang ada di lingkungan sekitar yang bisa dijadikan materi pembelajaran. Dari ketiga

Media memiliki peranan penting terhadap keberhasilan suatu pembelajaran. Kriteria pemilihan media menurut (Arsyad, 2014:74) meliputi (1) sesuai dengan tujuan yang ingin dicapai, (2) tepat untuk mendukung isi pelajaran yang sifatnya fakta, konsep, prinsip, atau generalisasi, (3) praktis, luwes, dan bertahan, (4) guru terampil menggunakannya, (5) pengelompokkan sasaran, dan (6) mutu teknis. Media yang dicantumkan dalam RPP adalah LCD dan buku. Pada pembelajaran guru menayangkan kethoprak. Kethoprak digunakan sebagai media untuk mencari contoh kalimat ataupun kata yang mengandung basa rinengga. Pada RPP guru hanya mencantumkan dua media tidak dicantumkan media berupa video.

\section{Menyusun Langkah-langkah Pembelajaran}

Langkah pembelajaran yang terdapat di dalam RPP dibagi menjadi terdiri dari kegiatan: awal, inti, dan penutup. Langkah-langkah pembelajaran yang tercantum dalam RPP dilaksanakan dalam dua kali pertemuan, dengan setiap pertemuan berlangsung selama 2x40 menit. Pembagian alokasi waktu pada RPP guru disetiap pertemuan dibagi sama rata dengan rincian, 10 menit untuk kegiatan pendahuluan, 60 
menit kegiatan inti, dan 10 menit penutup. Pembagian alokasi waktu tidak disesuaikan dengan kesulitan setiap kompetensi yang akan dipelajari.

Pada kegiatan awalguru menumbuhkan sikap spiritual kemudian peserta didik menerima informasi mengenai kompetensi, materi, tujuan, manfaat, dan langkah pembelajaran yang akan dilaksanakan. Kegiatan selanjutnya guru mengingatkan siswa mengenai pembelajaran sebelumnya. Hal ini bertujuan untuk untuk mengetahui kesiapan siswa pada saat akan menerima pembelajaran, untuk mengetahui apakah pikirannya masih kosong atau sudah siap menerima pelajaran.

Kegiatan apersepsi, untuk membangun konsep awal siswa guru memberikan pemodelan teks yang memuat ragam dan gaya bahasa. Kegiatan tanya jawab mengenai materi yang akan diajarkan juga dirancang oleh guru. Hal ini sesuai dengan pendapat Isdisusilo (2012:32) menyatakan bahwa aktivitas yang perlu dilakukan guru dalam kegiatan pendahuluan meliputi, (1) menyiapkan peserta didik secara psikis dan fisik untuk mengikuti proses pembelajaran, (2) mengajukan pertanyaan-pertanyaan yang mengaitkan pengetahuan sebelumnya dengan materi yang akan dipelajari, (3) menjelaskan tujuan pembelajaran atau KD yang akan dicapai, (4) menyampaikan cakupan materi dan penjelasan uraian kegiatan sesuai silabus.

Pada kegiatan inti guru menerapkan pola diskusi kelompok dan individu. Adanya dorongan siswa untuk bekerja sama dengan teman lain pada kelompok dapat menciptakan suasana yang aktif dan menyenangkan. Manfaat lain yang didapatkan ialah menumbuhkan motivasi dalam diri siswa serta meningkatkan kepercayaan dirinya untuk terpacu lebih aktif saat pembelajaran. Kegiatan inti yang ada di dalam RPP guru menggunakan pendekatan saintifik, terbukti dengan dicantumkan kriteria pendekatan saintifik $5 \mathrm{M}$ yakni mengamati, menanya, menalar/mengeksplorasi, mengasosiasi, dan mengomunikasikan.

Antusias siswa pada kegiatan inti di awal pembelajaran masih kurang maksimal, hal ini dikarenakan pengetahuan awal siswa kurang mengenai basa rinengga. Mereka hanya mendapatkan pengetahuan satu arah yakni dari buku pegangan siswa saja. Ketika guru menayangkan video kethoprak mereka antusias, karena hal ini belum pernah mereka ketahui sebelumnya dan inilah yang menarik minat peserta didik. Hal ini sesuai dengan pendapat Isdisusilo (2012:32) bahwa 
kegiatan inti merupakan proses pembelajaran untuk mencapai kompetensi dasar yang dilakukan secara interaktif, menyenangkan, menantang, memotivasi siswa untuk berpartisipasi aktif, serta memberikan ruang yang cukup bagi prakarasa, kreativitas, dan kemandirian sesuai dengan bakat,minat, dan perkembangan fisik serta psikologis siswa. Pada kegiatan inti ini dorongan dari guru serta media yang sesuai memegang peranan penting bagi keberhasilan suatu pembelajaran.

Kegiatan penutup peserta didik melaksanakan refleksi. Kegiatan refleksi dilakukan guru berupa menanyakan manfaat apa yang didapatkan selama pembelajaran dan kesulitan apa yang dihadapi. Peserta didik juga diberikan kesempatan untuk menyampaikan usulan untuk pembelajaran berikutnya. Guru juga memberikan penjelasan mengenai materi serta tugas kepada peserta didik untuk pertemuan selanjutnya. Isdisusilo (2012:35) bahwa kegiatan penutup harus merencanakan kegiatan tindak lanjut. Langkah-langkah pembelajaran yang telah disusun oleh guru tidak semua dilaksanakan sesuai dengan rancangan. Hal ini terlihat pada beberapa poin, di antaranya ketika pendidik dan peserta didik menyepakati langkah-langkah kegiatan yang akan ditempuh untuk mencapai kompetensi tidak dilaksanakan oleh guru. Guru memegang kendali penuh selama pembelajaran.

\section{Menyusun Penilaian Pembelajaran}

Penilaian pembelajaran yang disusun guru meliputi penilaian pengetahuan dan penilaian keterampilan. Pada penilaian pengetahuan guru menggunakan teknik penilaian tes tertulis dengan bentuk instrument uraian. Sanjaya (2011:187) menyatakan bahwa tes adalah teknik penilaian yang biasa digunakan untuk mengukur kemampuan siswa dalam pencapaian suatu kompetensi tertentu. Kisi-kisi penilaian pengetahuan yang dibuat, guru mencantumkan indikator dan butir instrumen. Selain membuat penilaian pengetahuan guru juga mencantumkan rubrik penilaian guna mempermudah proses penilaian.

Pada penilaian keterampilan guru menggunakan teknik penilaian berupa tes tertulis dengan bentuk instrument rubrik penilaian. Pada kisi-kisi penilaian guru mencantumkan keterampilan dan butir instrumen. Pada RPP tidak dicantumkan mengenai penilaian sikap oleh guru. Nilai sikap kepada peserta didik yang diamati pada saat kegiatan belajar mengajar sedang berlangsung. Penilian sikap digunakan 
oleh guru sebagai penilaian proses ketika peserta didik mengikuti pembelajaran. Penilaian sikap yang dilakukan oleh guru saat ini memiliki kriteria seperti anak yang rajin mengerjakan tugas, anak yang aktif di dalam kelas, anak yang tidak mengerjakan tugas yang diberikan. Hal seperti ini dapat menimbulkan ketimpangan nilai bagi peserta didik karena guru belum memiliki kriteria penilaian sikap yang jelas bagi masing-masing peserta didiknya dan bisa saja penilaian bersifat subyektif.

Dari kegiatan penilaian yang telah direncanakan oleh guru terdapat kisi-kisi dan lembar observasi penilaian. Penilaian yang tercantum dalam RPP belum menggunakan penilaian berbentuk rubrik. Hal ini belum sesuai dengan pendapat Purwanto (2012:75) bahwa sistem penilaian yang digunakan hendaknya jelas baik untuk siswa maupun guru.

\section{Pelaksanaan Pembelajaran Gaya Bahasa (Basa Rinengga)}

\section{Kegiatan Awal Pembelajaran}

Kegiatan pendahuluan di awali dengan berdoa, memberi salam dan memeriksa kehadiran siswa serta memberikan motivasi singkat kepada siswa. Guru menjelaskan mengenai materi yang akan disampaikan dan memberikan pertanyaanpertanyaan terkait materi sebelumnya. Guru juga mengaitkan manfaat pembelajaran dalam kehidupan sehari-hari dan juga mengemukakan tujuan yang akan dicapai dalam pembelajaran.

Kegiatan awal pembelajaran guru selalu mengingatkan kembali siswa mengenai pembelajaran sebelumnya. Hal ini dilakukan oleh guru untuk mengetahui kesiapan siswa pada saat akan menerima pembelajaran, untuk mengetahui apakah pikirannya masih kosong atau tidak. Harapan guru melaksanakan kegiatan me-recall pengetahuan siswa dulu supaya siswa tidak melupakan begitu saja pembelajaran yang telah berlalu. Selain itu tujuan guru membuka pelajaran dengan menyampaikan materi yang akan diajarkan ialah agar siswa mengetahui tujuan pembelajaran serta mempermudah untuk merencanakan kegiatan pembelajaran berikutnya. Perencaan ataupun langkah-langkah pembelajaran yang akan dilaksanakan pada RPP guru adanya campur tangan siswa mengenai pendapat mereka tentang pembelajaran selanjutnya belum dilaksanakan. Padahal dalam RPP sudah dicantumkan dengan jelas pada poin keenam pada pertemuan pertama dan poinkeempat pada pertemuan kedua. 


\section{Kegiatan Inti Pembelajaran}

Pelaksanaan kegiatan inti dimulai dengan guru menayangkan materi berupa power point kemudian siswa mencatat materi yang sudah disediakan oleh guru diselingi penjelasan dari guru untuk mempermudah pemahaman mereka mengenai materi yang diajarkan. Pada tahap ini masih dominan ceramah dari guru, hal ini terjadi karena siswa hanya memiliki sedikit pengetahuan dasar mengenai basa rinengga. Guru melaksanakan tindak lanjut mengenai pertanyaan siswa baik dalam kelompok ataupun individu. Umpan balik diberikan oleh guru mengenai permasalahan yang ditemukan oleh siswa. Guru memberi tugas kelompok dan menugaskan presentasi hasil diskusi kelompok serta membahas bersama semua pekerjaan yang telah dituliskan. Guru memberikanreward berupa nilaikepada setiap anggota kelompok yang maju untuk menuliskan hasil diskusi kelompok mereka.

Pada kegiatan inti yang dilakukan, guru sudah menggunakan media dalam pembelajaran basa rinengga ini. Namun, pada saat pemberian tugas guru kurang tegas dalam hal pemberian batas waktu mengerjakan. Hal ini sesuai dengan pendapat Mulyasa (2013:127) yang menyatakan bahwa dalam kegiatan inti pembelajaran harus mencakup penyampaian informasi, membahas materi standar untuk membentuk karakter dan kompetensi peserta didik, serta melakukan tukar pengalaman dan pendapat dalam membahas materi dan memecahkan masalah. Tidak hanya tugas kelompok akan tetapi guru membahas soal-soal yang terdapat pada LKS ataupun buku paket secara langsung.

Strategi pembelajaran berkelompok di kegiatan inti pada saat penugasan dipilih guru untuk memudahkan peserta didik dalam mengerjakan tugas yang diberikan. Di dalam kelompok mereka bisa bekerja dengan cara tukar pendapat sehingga mereka tidak bosan ketika harus bekerja secara individu serta mengurangi pekerjaan yang asal-asalan dari peserta didik. Kendala yang dialami guru ialah siswa kurang antusias ketika belajar mengenai bahasa Jawa khususnya basa rinengga, hal ini disebabkan kurang beragamnya media serta pengetahuan awal siswa mengenai basa rinengga kurang. Di awal pertemuan guru hanya menggunakan power point, setelah di pertemuan kedua peserta didik lebih antusias karena guru menampilkan 
kethoprak. Pada pertemuan kedua, siswa secara mandiri melakukan kegiatan mengamati, menanya, mengumpulkan informasi, menalar.

RPP yang telah dirancang oleh guru belum sepenuhnya dirujuk oleh guru dalam pelaksanaan pembelajaran. Misalnya, guru tidak memunculkan pembelajaran mengenai paribasan sesuai dengan langkah-langkah pembelajaran yang sudah dirancang. Akibat dari pembelajaran yang tidak sesuai dengan rancangan, maka susunan rencana pembelajaran akan berubah. Misalnya, kegiatan mengamati kethoprak serta mencari kalimat atau kata yang mengandung basa rinengga pada pertemuan kedua tidak tuntas dengan alokasi waktu 60 menit. Akhirnya kegiatan pertemuan kedua dilanjutkan pada pertemuan selanjutnya tanpa adanya rancangan pembelajaran. Maka dari itu, alokasi waktu sangat penting supaya rencana yang dibuat berjalan sesuai dengan yang dirancang.

\section{Kegiatan Akhir Pembelajaran}

Kegiatan akhir yang dilakukan guru pada setiap pertemuan ialah menyampaikan rencana pembelajaran pada pertemuan selanjutnya. Penyampaian rencana pembelajaran berupa pekerjaan rumah pada siswa pada pertemuan kedua serta pada akhir pembelajaran yakni pada pertemuan ketiga akan dilaksanakan ulangan harian. Pada pertemuan pertama guru memberi tugas untuk mengerjakan LKS. Pertemuan kedua karena waktu tidak mencukupi guru memberikan tugas agar hasil diskusi kelompok dilanjutkan di rumah dan pembahasan dilaksanakan pada pertemuan selanjutnya. Hasil diskusi kelompok belum bisa dikomunikasikan dengan teman-temannya, dengan kata lain pembelajaran tidak tuntas pada pertemuan kedua.

Pada setiap pertemuan guru selalu melaksanakan refleksi. Refleksi yang dilaksanakan oleh guru bersifat terbimbing. Artinya, guru selalu melibatkan siswa dalam menyimpulkan sesuatu selanjutnya guru memberikan penguatan di akhir pembelajaran mengenai simpulan yang telah dikemukakan oleh siswa.

\section{Penilaian Pembelajaran Gaya Bahasa (Basa Rinengga)}

Penilaian pembelajaran gaya bahasa (basa rinengga) meliputi tiga aspek, yaitu penilaian sikap (spiritual dan sosial), penilaian pengetahuan, dan penilaian keterampilan. Harsiati (2012:122) penilaian hasil menentukan seberapa luas dan seberapa dalam perubahan pengetahuan, keterampilan, dan sikap yang dialami siswa 
setelah pelaksanaan program pembelajaran. Penilaian pengetahuan dan penilaian keterampilan sudah nampak jelas dalam pembelajaran gaya bahasa (basa rinengga).

Penilaian pengetahuan tercermin ketika proses pembelajaran siswa mendapatkan materi mengenai pengertian dari basa rinengga, contoh dan jenis dari basa rinengga, serta ciri-ciri dari basa rinengga. Penilaian pengetahuan juga tercermin pada ulangan harian. Aspek keterampilan terlihat ketika perwakilan kelompok mempresentasikan hasil kerja kelompok mereka di depan teman-temannya. Kemudian guru memberi tahu kesalahan dan melakukan pembenaran terhadap pekerjaan siswa dan di akhir selalu memberi penguatan.

Berdasarkan hasil wawancara dengan guru bahasa Jawa SMPN 2 Malang, penilaian sikap dilakukan pada saat pembelajaran berlangsung di kelas. Berikut kutipan wawancara dengan guru.

\footnotetext{
"Kalau saya penialain sikap itu tidak per bab. Jadi setiap kali masuk itu saya ada penilaian sikap dan penilaian sikap cenderung aktif dan tidak, kalau misalkan kalau anak ini ada catatan anak ini melakukan apa gitu baru saya catat, jadi nggak per bab itu saya kasih nilai selalu ada catatan, seperti nggak mengerjakan pekerjaan rumah, atau nggak bawa buku dsb.”
}

Pada kutipan di atas terlihat bahwa guru menilai sikap siswa dari observasi, tidak menggunakan lembar penilaian yang memiliki kriteria jelas untuk penilaian sikap sehingga kemungkinan untuk bersikap subyektif lebih besar. Berdasarkan temuan, penilaian sikap belum dilakukan ke seluruh siswa. Guru hanya mencatat siswa yang aktif dalam pembelajaran dan siswa yang kurang mentaati peraturan seperti halnya ada catatan kasus dan tidak membawa buku atau tidak mengerjakan tugas rumah.

Penilaian pembelajaran yang berlangsung di dalam kelas yakni penilaian pengetahuan pada pertemuan ketiga. Pertemuan keterampilan terlihat pada pertemuan ketiga di awal pembelajaran yakni melanjutkan kegiatan penilaian pertemuan kedua yang belum selesai. Penilaian sikap dilaksanakan setiap saat ketika pembelajaran berlangsung. Penilaian secara keseluruhan dilakukan oleh guru tanpa adanya campur tangan siswa dalam proses penilaian. 


\section{PENUTUP}

\section{Simpulan}

Berdasarkan hasil penelitian tentang pembelajaran gaya bahasa (basa rinengga) pada siswa kelas VIII SMPN 2 Malang ditarik tiga simpulan, yaitu perencanaan pembelajaran, pelaksanaan pembelajaran, dan penilaian pembelajaran.

Pertama, perencanaan pembelajaran gaya bahasa (basa rinengga) memuat seluruh komponen RPP meliputi (1) identitas RPP, (2) standar kompetensi, kompetensi dasar, dan tujuan pembelajaran, (3) pengembangan materi dan bahan ajar, (4) pendekatan, metode dan model pembelajaran, (5) langkah-langkah pembelajaran,dan (6) penilaian. RPP yang dilaksanakan oleh guru disusun berkelompok dalam satu tim MGMP. Kompetensi inti tidak dicantumkan oleh guru bahasa Jawa SMPN 2 Malang dalam RPP.

Kedua, pelaksanaan pembelajaran gaya bahasa (basa rinengga) dilaksanakan tiga kali pertemuan dengan alokasi waktu setiap pertemuan 2x40 menit. Kegiatan yang dilakukan terdiri atas kegiatan: awal, inti, dan penutup. Pelaksanaan kegiatan awal, yaitu guru membuka pelajaran dengan mengucapkan salam dan berdoa dilanjutkan dengan presensi. Kegiatan selanjutnya apersepsi, motivasi serta mengaitkan manfaat kompetensi yang dipelajari terhadap kehidupan sehari-hari siswa.Kegiatan inti terlihat ada penjelasan dari guru mengenai prosedur kegiatan. Tidak ditemukan adanya salah konsep dalam pemberian materi ajar, hal ini terlihat ketika guru mulai berinteraksi dengan siswa membahas contoh dari penggunaan basa rinengga pada teks panyandra dan tayangan contoh basa rinengga lainnya. Guru menyampaikan tugas untuk pertemuan selanjutnya. Kegiatan penutup berupa kegiatan refleksi. Guru memberikan refleksi pembelajaran pada pertemuan pertama dan pertemuan ketiga. Kegiatan refleksi dilaksanakan secara terbimbing, siswa diberikan kesempatan untuk mengungkapkan apa saja yang telah mereka dapatkan kemudian diakhir guru memberikan penguatan.

Ketiga, penilaian pembelajaran gaya bahasa (basa rinengga) terdiri atas penilaian: sikap, keterampilan, dan pengetahuan. Penilaian sikap dilaksanakan ketika pembelajaran berlangsung. Kriteria penilaian sikap guru seperti siapa anak yang tidak mengerjakan tugas dan siswa yang tidak membawa buku pelajaran. Penilaian 
keterampilan terlihat ketika siswa secara bergantian maju mempresentasikan hasil diskusi, penilaian tercermin setelah membahas pekerjaan siswa guru menanyakan nama anggota kelompok. Penilaian pengetahuan terlihat ketika dilaksanakannya ulangan harian dan juga tanya jawab ketika pembelajaran. Rubrik penilaian keterampilan dan pengetahuan sudah tercantum jelas dalam RPP.

\section{Saran}

Berdasarkan simpulan di atas disampaikan saran bagi guru, sebaiknya mempersiapkan RPP lebih rinci pada beberapa kegiatan, misal pada penilaian sikap diberikan rubrik penilaian yang jelas. Hal ini bertujuan supaya RPP yang disusun mudah dipahami oleh orang lain dan memudahkan dalam pelaksanaannya.Bagi peneliti lain, disarankan untuk mengembangkan bahan ajar bahasa Jawa yang bisa menarik minat siswa sehingga meningkatkan mutu pembelajaran basa rinengga.

\section{DAFTAR RUJUKAN}

Arsyad, Azhar. 2014. Media Pembelajaran. Jakarta: Rajawali Pers.

Harsiati, Titik. 2011. Penilaian dalam Pembelajaran: Aplikasi dalam Pembelajaran Membaca dan Menulis. Malang: UM Press.

Isdisusilo. 2012. Panduan Lengkap Menyusun Silabus dan Rencana Pelaksanaan Pembelajaran. Jakarta: Kata Pena.

Mulyasa, E. 2015. Menjadi Guru Profesional: Menciptakan Pembelajaran Kreatif dan Menyenangkan. Bandung: Remaja Rosdakarya.

Mulyasa, E. 2015. Pengembangan dan Implementasi Kurikulum 2013. Bandung: Remaja Rosdakarya.

Padmosoekotjo. 1953. Ngengrengan Kasusastran Djawa. Yogyakarta: Hien Hoo Sing.

Priyatni, E.T. 2014. Desain Pembelajaran Bahasa Indonesia dalam Kurikulum 2013. Jakarta: Bumi Aksara.

Poerwanti, E. L dan Amri, S. 2013. Panduan Memahami Kurikulum 2013. Jakarta: Prestasi Pustaka Publiser.

Purwanto, N. M. 2012. Prinsip-prinsip dan Teknik Evaluasi Pengajaran. Bandung: Remaja Rosdakarya.

Sabdawara. 2001. Pengajaran Bahasa Jawa sebagai Wahana Pembentukan Budi Pekerti Luhur. Yogyakarta: Panitia Kongres Bahasa Jawa III. 
Sanjaya, H.Wina. 2013. Perencanaan \& Desain Sistem Pembelajaran. Bandung: Kencana Prenadamedia Groub. 